\title{
Kariyer Tatmini ve İşten Ayrılma Niyeti Arasındaki İlişkide İşe Adanmışlığın Aracılık Rolü (The Mediating Role of Job Engagement in the Relationship Between Career Satisfaction and Intention to Quit)
}

\author{
Ayşe ANAFARTA iD a Özkan YILMAZ iD b \\ a Antalya AKEV Üniversitesi İ̈BF İşletme Bölümü, Antalya, Türkiye. ayse.anafarta@akev.edu.tr \\ b Antalya AKEV Üniversitesi İ̈BF İşletme Bölümü, Antalya, Türkiye. ozkan.yilmaz@akev.edu.tr
}

\begin{tabular}{|c|c|}
\hline MAKALE BİLGİSI & ÖZET \\
\hline $\begin{array}{l}\text { Kariyer Tatmini } \\
\text { İse Adanmıslık }\end{array}$ & $\begin{array}{l}\text { Amaç - Bu araştırma, işe adanmışlığın kariyer tatmini ve işten ayrılma niyeti arasındaki aracılık } \\
\text { rolüne odaklanarak çalışanları elde tutma konusunda alanyazına katkıda bulunmayı } \\
\text { amaçlamaktadır. }\end{array}$ \\
\hline $\begin{array}{l}\text { İşten Ayrılma Niyeti } \\
\text { Aracılık Etkisi } \\
\text { Yapısal Eşitlik Modellemesi }\end{array}$ & $\begin{array}{l}\text { Yöntem - Tanımlayıcı tipteki bu araştırmaya Antalya'da bankacıllk sektöründe görev yapan } 285 \text { kişi } \\
\text { katılmıştır. Çalışmada kariyer tatmini ve işten ayrılma niyeti arasındaki ilişkide işe adanmışlığın } \\
\text { aracılık rolü yapısal eşitlik modeli kullanılarak test edilmiştir. }\end{array}$ \\
\hline $\begin{array}{l}\text { Gönderilme Tarihi } 2 \text { Eylül } \\
2019 \\
\text { Revizyon Tarihi } 30 \text { Kasım } 2019 \\
\text { Kabul Tarihi } 6 \text { Aralık } 2019\end{array}$ & $\begin{array}{l}\text { Bulgular - Bulgular kariyer tatmini ile işe adanmışlık boyutları (dinçlik, adanma ve yoğunlaşma) } \\
\text { arasında pozitif, kariyer tatmini ile işten ayrılma niyeti arasında negatif doğrudan bir ilişkinin } \\
\text { olduğunu göstermiştir. İşe adanmışlğ̆ı üç boyutu (dinçlik, adanma ve yoğunlaşma) ile işten } \\
\text { ayrılma niyeti arasında negatif bir ilişki bulunmuştur. Yapısal eşitlik modelinin sonuçlarına göre işe } \\
\text { adanmışlığın dinçlik ve yoğunlaşma boyutları kariyer tatmini ile işten ayrılma niyeti arasındaki } \\
\text { ilişkide tam aracıllk rolüne sahiptir. }\end{array}$ \\
\hline $\begin{array}{l}\text { Makale Kategorisi: } \\
\text { Araştırma Makalesi }\end{array}$ & $\begin{array}{l}\text { Tartışma - Araştırma sonuçlarına göre, kariyer tatmin düzeyleri yüksek olan banka çalışanlarının } \\
\text { işe adanmışlıklarının artması neticesinde, işten ayrılma niyetleri azalmaktadır. Çalışanların kariyer } \\
\text { tatminlerindeki artış işe adanmışlık düzeylerini yükseltmektedir. Aynı zamanda, işe adanmışlık } \\
\text { düzeyi, özellikle yoğunlaşma boyutu yüksek olan çalışanlar diğer çalışanlara nazaran işlerinde daha } \\
\text { fazla mutlu olmaları ve işlerinde zamanın hızlı geçtiğini hissetmeleri sonucunda işlerinden } \\
\text { ayrılmayı daha az düşünmeye eğilimlidirler. Bu araştırma hem kariyer tatmininin hem de işe } \\
\text { adanmışlığın işten ayrılma niyetini tahmin etmede önemli olduğunu göstermiştir. Dolayısıla } \\
\text { araştırma bulguları, işe adanmışlık ve kariyer tatminini geliştirici programların hazırlanmasının } \\
\text { çalışanları elde tutma olasılığını artırabileceği gerçeğini ortaya koymaktadır. }\end{array}$ \\
\hline
\end{tabular}

\begin{tabular}{ll}
\hline ARTICLE INFO & ABSTRACT \\
\hline $\begin{array}{l}\text { Keywords: } \\
\text { Career Satisfaction }\end{array}$ & $\begin{array}{l}\text { Purpose - This study aims to contribute to the literature on employee retention by focusing on the } \\
\text { rob Engagement }\end{array}$ \\
$\begin{array}{l}\text { Intention to Quit } \\
\text { Mediation Analysis } \\
\text { Structural Equation Modeling } \\
\text { banking sector in Antalya. In the study, the mediating role of job engagement between career } \\
\text { satisfaction and intention to quit is tested using the structural equation model. }\end{array}$ \\
$\begin{array}{l}\text { Feceived 2 September 2019 } \\
\text { Revised 30 November 2019 } \\
\text { Accepted 6 December 2019 }\end{array}$ & $\begin{array}{l}\text { and job engagement dimensions (vigor, dedication and absorption), and a negative relation between } \\
\text { career satisfaction and intention to quit. A negative relationship was found between the three } \\
\text { dimensions of job engagement (vigor, dedication and absorption) and intention to quit. According } \\
\text { to the structural equation model, vigor and absorption dimensions of the job engagement have a full } \\
\text { mediating role in the relationship between career satisfaction and intention to quit. }\end{array}$ \\
Article Classification: & $\begin{array}{l}\text { Discussion - According to the research results, for the employees who have a high career } \\
\text { satisfaction, the intention to quit decreases when their job engagement increases. The increase in the } \\
\text { career satisfaction of the employees increases their levels of job engagement. Additionally, } \\
\text { employees with a high level of job engagement tend to think less of leaving as a result of the fact } \\
\text { that employees with high absorption levels are more happy in their jobs and feel that time passes } \\
\text { quickly in their jobs compared to other employees. This research has shown that both career } \\
\text { satisfaction and job engagement are important in predicting intention to quit. Therefore, the findings } \\
\text { of the research reveal the fact that the preparation of programs that improve job engagement and } \\
\text { career satisfaction may increase the likelihood of retaining employees. }\end{array}$
\end{tabular}




\section{Giriş}

İşletmeler rekabet edebilirliklerini sürdürebilmek için çalışanlarını elde tutabilmeli ve işgücü devri oranlarını azaltabilmelidirler (Mohlala vd., 2012). Günümüzün rekabetçi dünyasında işletmeler verimlilik, iş tatmini, işe adanmışlık, işten ayrılma niyetinin azaltılması gibi alanlarda sorunlar yaşamaktadırlar (Langelaan vd., 2006; İnce, 2016). Çalışanlarını örgütte tutabilmek ve işten ayrılma niyetlerini azaltabilmek örgütler için giderek daha önemli hale gelmektedir. Çalışanların örgüte devamlılıklarını sağlayabilmenin ve elde tutabilmenin önemli yollarından birisi, çalışanların kariyer tatmin düzeylerinin ve işlerine olan adanmışlık düzeylerinin arttırılmasıdır. Buna karşılık çalışanların işgücü devri son yıllarda en yüksek seviyeye ulaşmış durumdadır. CIPD tarafından 2017 yılında yayımlanan bir raporda, örgütlerin yüzde sekseninden fazlasının bir veya daha fazla çalışanı elde tutmakta zorlandığı ortaya çıkmıştır (CIPD, 2017). İşletmelerin çalışanlarını ellerinde tutmalarının gittikçe zorlaşması nedeniyle işgücü devri ve işten ayrılma niyeti gibi örgütsel sonuçlar akademisyenler için önemli bir konu olmaya devam etmektedir (Yang vd., 2012).

İşe adanmışlık, İnsan Kaynakları Yönetimi alanında önemli bir konu olarak ortaya çıkmıştır (Venkatesh ve Lissy, 2014:209) ve son yıllarda hem uygulamacıların hem de araştırmacıların dikkatini çekmektedir (Mxrnge vd., 2014; Kartal vd., 2015; Pollak vd., 2017). İşe adanmışlı̆ın yapısının stratejik olarak anlaşılması için onun öncüllerinin araştıılması gerekir. Az sayıda araştırma, işe adanmışlığın sınırlı nedenleri ve belirli sonuçları arasındaki ilişkiyi araştırmaktadır (Barnes ve Collier, 2013; Kane-Frieder vd., 2014; Lee vd., 2016). İşe adanmışlığın faklı öncüllerle ilişkilerinin ele alınmasına gereksinim vardır. Bu öğelerden birisi kariyer tatminidir. Çalışanların mutluluğunu etkileyebilecek ve örgütlerin dış müşterilerini mutlu ederek karlarını arttırabilecek bir değişken olan kariyer tatmini (Martins vd., 2002), çalışanların işlerine daha bağlı kalmalarını sağlayabildiği gibi kendilerini işlerine adama düzeylerini de arttırabilecektir. Ryan ve Deci (2000), kariyer tatmininin bireyin içsel psikolojik gereksinimlerini ne ölçüde gerçekleştirdiğinin bir değerlendirmesini sağladığına ve kariyer tatmininin işe adanmışlıkla önemli ölçüde ilişkili olduğuna işaret etmektedirler. Timms ve Brough (2013:773), kariyer tatmininin çalışanların uzun vadeli adanmışlığına bağlı olduğunu ve kariyer tatmininin işe adanmışlı̆̆ın güçlü bir belirleyicisi olduğunu ifade etmektedirler. İşe adanmışlık ve kariyer arasındaki ilişkinin kapsamlı bir şekilde anlaşılması, bireysel çalışanların işe adanmışlık seviyelerini artırmak, kariyerle ilgili stratejiler tasarlamak ve uygulamak isteyen insan kaynakları uzmanları için faydalıdır (Lee vd., 2016:30).

İşe adanmışlığın anlaşılması açısından öncül değişkenlerin yanısıra sonuçlarının da incelenmesinde fayda vardır. Fiili olarak işten ayrılmanın en önemli belirtisi olan işten ayrılma niyeti işletmeler için önemli bir sorun niteliğindedir. İşten ayrılma niyeti çalışan işgücü devri davranışını biçimlendirmede anahtar bir eleman olarak incelenmektedir (Anafarta, 2015:72). Saks (2006), çalışan adanmışlığının, çalışanların tutumları, niyetleri ve davranışlarıyla ilişkili olduğunu ifade etmektedir. Al-Shbiel vd. (2018), işe adanmışlığın çalışanların tutumları, niyetleri ve davranışlarıyla ilişkili olduğunu ve işine adanmış çalışanların örgülerine daha fazla katkıda bulunduklarını söylemektedir.

Herhangi bir örgütün başarısı ve başarısızlığı işgücüne bağlıdır ve işgücü araştırmacıların çoğu tarafından herhangi bir örgütün bel kemiği olarak kabul edilir. Verimli işgücüne sahip olmak örgütün küresel pazarda büyümesine yardımcı olmaktadır (Memon, vd., 2018:166). İşgücünün önemli kavramlarından biri olan işe adanmışlık, performans yönetimi, kişisel gelişim, büyüme, kariyer tatmini, iş tatmini ve ücretlendirmeden büyük ölçüde etkilenmektedir (Dutta ve Sharma, 2016:189). Düşük adanmışlık ve tatmin, işgücü devrini ve işten ayrılma niyetini arttırırken, firma performansını ve verimliliği de azaltabilir. Kariyer tatmini bireysel ve örgüt performansı için önemli olduğu kadar işe gelme, işten ayrılma niyeti ve işgücü devir oranını da azaltmaktadır (Jiang vd., 2001; August ve Waltman, 2004: 178; Eddleston, 2009; Guan vd., 2014;). Wright ve Bonett (2007), kariyer tatmininin işgücü devri oranının önemli bir belirleyicisi olduğunu ileri sürmüşlerdir. İşten ayrılma niyetinin incelenmesi, örgütün işine kendini adayan çalışanların işten ayrılmayı planlayıp planlamadıkları ve niçin ayrılmayı düşündüklerinin belirlemesinde yardımcı olacaktır.

Bu araştırma, örgütlerin çalışanlarını elde tutmaları ve yüksek örgütsel başarıyı yakalamaları açısından önemli olan kariyer tatmini, işe adanmışlık ve işten ayrılma niyeti ilişkisini daha iyi anlamalarına yardımcı olacaktır. Ayrıca araştırmada, kariyer tatmini ve işten ayrılma niyeti arasındaki ilişkide işe adanmışlığın aracılık rolünün incelenerek işe adanmışlık kadar kariyer tatmini alanında da incelenmemiş olan aracı değişkenlerden birini irdelemekle kariyer tatmini alanyazınının genişlemesine katkıda bulunulacaktır. 


\section{A. Anafarta - Ö. Y1lmaz 11/4 (2019) 2944-2959}

\section{Kuramsal Çerçeve ve Hipotezler}

\section{1. İşe Adanmışlık}

Tükenmişliğin pozitif anti tezi olarak ifade edilen işe adanmışlık kavramı (Schaufeli ve Bakker, 2004; Bakker vd., 2014), çalışanların bağlılık ve motivasyon eksikliği sorununun odak noktasını oluşturmaktadır (May vd., 2004:12). İşe adanmışlık kavramı, işte kalıcı, olumlu, tatmin edici duygusallık hali, enerji dolu olma ve tamamen işine adanma olarak tanımlanır (Gökaslan, 2018: 26). Çalışanlar kendilerini işlerine adadıklarında işlerini istekle yapabilir, tüm dikkatlerini yaptıkları işe verebilir ve yaptıkları işten zevk alabilirler. Ayrıca kişilerin kendilerini işlerine adamaları sebebiyle işlerine uzun süre konsantre olabilecekleri, yaptıkları işleri sahiplenecekleri ve başarılı olmak için yoğun çaba gösterecekleri, bunların da örgüt açısından olumlu sonuçlar ortaya çıkaracağı düşünülebilir (Pollak vd., 2017). İşlerine adanmış olan çalışanlar, kendilerini işleriyle özdeşleştirir ve işin kendisinden motive olurlar. Daha çok çalışma eğilimi gösterirler, diğer çalışanlardan daha verimli çalışırlar, müşterilerin ve örgütün istediği sonuçları ortaya çıkarma konusunda daha başarılıdırlar (Robert ve Davenport, 2002: 21). İşe adanmışlık, çalışanların işlerine yoğun enerji ile yaklaşıp, kendilerini adayarak bütünleştikleri bir yapıyı ifade etmektedir (Schaufeli vd., 2002). May vd. (2004), kişinin işini psikolojik olarak değerlendirdiğini ve işe adanmışlığın temel psikolojik gereksinimlerin gerçekleştirilmesini temsil eden bir durum olarak görülmesi gerektiğinin altını çizmektedir.

İşe adanmışlık güdüsel bir süreç ve üç boyutlu bir kavram olarak incelenmektedir (Takawira vd., 2014; Shimazu vd., 2015: 22). Geniş bir şekilde kabul gören boyutlardan dinçlik, yüksek düzeyde bir enerji ve çalışırken ruhsal iyileşme gücü olarak nitelendirilmektedir. Dinçlik, bireyin çalışma faaliyeti sürecinde sahip olduğu enerji düzeyi, çaba gösterme azmi ve zihinsel dayanıklılığını temsil etmektedir. Çalışma faaliyetinin kendisi ile güdülenen birey zorluklar karşısında enerjisini, azmini ve kararlılığını yitirmeden çalışma faaliyetini sürdürür (Timms ve Brough, 2013: 771). Ryan ve Deci (2000), işe adanmışlı̆̆ın başka bir boyutu olan adanmayı, işe adanma vasıtasıyla "son derece canll, hayat dolu olma duygusu" olarak tanımlamaktadır. Adanma, bireyin çalışmasına yüklenmesi anlamındadır. Bir başka deyişle, birey çalışma faaliyetinin ilgi çekici olduğunu ve bir amaca hizmet ettiğini düşünür. Bu ilgi çekici ve amaçlı faaliyeti sürdürürken şevk, ilham, övünç gibi duyguları yaşar. Bu duyguları yaşayan bireyin doğal olarak, yaptığı işe yönelik güçlü bir bağlılı̆̆1 söz konusudur. Yoğunlaşma (işe kendini verme) ise, zamanın hızla geçtiği ve kişinin kendisini işinden zorla ayırdığ Yoğunlaşma, bireyin faaliyete odaklanmasını ifade eder. Çalışma faaliyetine odaklanmış bir birey mutluluk duygusu yaşar, kendisini yaptığı işine kaptırır ve zaman kavramını unutur (Baker ve Simon, 2018). Dinçliği, adanmışlı̆̆ı ve yoğunlaşması güçlü olan bireyler çalışmaya adanmışlardır (Pinear ve Willemse, 2008: 1055; Burke vd., 2012: 11).

\subsection{Kariyer Tatmini ve İşe Adanmışlık İlişkisi}

Son yıllarda yönetim alanyazınında kariyer ve kariyer tatmini kavramı, çalışan gereksinimleri ile örgüt gereksinimlerinin karşılıklı tatmin edilebilmesi gerekliliği nedeniyle önem kazanan konular arasında yer almaktadır (Özgen ve Yalçın, 2010: 187; Lee vd., 2016). Alanyazına bakıldığında kariyer ile ilgili tüm kavramlarda oldukça fazla çalışmaya rastlanmakla birlikte, kariyer tatmini boyutunda oldukça az çalışmanın varlığ 1 dikkat çekmektedir. Özellikle kariyer tatmini ile işe adanmışlık arasındaki ilişkileri inceleyen çok az sayıda çalışma bulunmaktadır (Lee vd., 2016).

Alanyazında kariyer tatmini, genel olarak "bir bireyin kariyer başarıları ile ilgili tatmini" şeklinde tanımlanan öznel kariyer başarısı olarak değerlendirilmektedir (Barnett ve Bradley, 2007; Yap vd., 2010). Shaver ve Lacey (2003), kariyer tatminini “bir bireyin kendisine kariyer seçmesi ve iş deneyimlerinin seçtiği o kariyeri ne kadar doğruladığı" şeklinde tanımlamıştır. Lounsbury vd. (2008), işle ilgili tatmin türlerinden birisi olan kariyer tatmininin, bireylerin kişisel olarak kariyer hedeflerine ulaşıp ulaşmadığının göstergesi olduğunu, çalışanların kariyerlerine karşı tutumlarından ve işle ilgili tüm duygularından oluştuğunu ifade etmişlerdir. Kariyer tatmini, bireyin özlemlerinden, ilgisinden, istihdamindan ve yeteneklerinden kaynaklanan duygusal bir durumudur.

Kariyer, örgütsel sürekliliği sağlamak için zaman ve para yatırımıyla ilişkili önemli bir araçtır. Bu durum, bir örgütün kariyer yönetiminden elde edebileceği faydalarla ilgili merakı artırmaktadır (Singh, 2018). Markos ve Sridevi (2010), çalışanlara gelişim ve ilerleme için tatmin edici fırsatlar sunmanın çalışanın işe adanmışlığını 


\section{A. Anafarta - Ö. Y1lmaz 11/4 (2019) 2944-2959}

arttırdığı sonucuna ulaşmışlardır. Çalışanlar, adanmışlıkları arttıkça genel kariyerlerinden daha çok memnun olacaklar ve adanmış olan çalışanlar daha yüksek düzeyde bir mutluluk algılayacaklardır (Joo ve Lee, 2017). Lee vd. (2016)'ye göre işe adanmışlık, yönetim bilimi alanında en çok çalışılan konulardan biridir ve insan kaynağı gelişiminin performansa dayalı çeşitli bakış açılarından, çalışanların kariyerleriyle yakından ilgilidir. Bu bilgilerin ışığında, kariyer tatmininin işe adanmışlık boyutları olan dinçlik, adanma ve yoğunlaşma ile ilişkili olduğu söylenebilir. Kariyer tatmininin, işe adanmışlı boyutları üzerinde etkili olabileceği düşüncesiyle aşağıdaki hipotezler sınanacaktır.

\section{H1: Kariyer tatmini ile dinçlik boyutu arasında pozitif yönlü bir ilişki vardır.}

H2: Kariyer tatmini ile adanma boyutu arasında pozitif yönlü bir ilişki vardır.

H3: Kariyer tatmini ile yoğunlaşma boyutu arasında pozitif yönlü bir ilişki vardır.

\section{3. İşe Adanmışlık ve İşten Ayrılma Niyeti İlişkisi}

İşe adanmışlık ve işten ayrılma niyeti, kurumsal başarı ve başarısızlığın önemli belirleyicileri olan iki faktördür. Bunlar, örgütlerin işgücüyle ilgili temel göstergelerdir (Salahudin, 2019). Çalışan adanmışlı̆̆ı, insan kaynaklarının gündeminde üst sıralarda yer almaktadır. İşe adanmışlık psikoloji, yönetim, örgütsel davranış ve diğer disiplinlerde en güncel araştırma konularından biri olarak ortaya çıkmıştır (Pollak vd., 2017:175). Diğer yandan işten ayrılma niyeti, yönetim araştırmacıları arasında ilgi alanı olmaya devam etmektedir (Gupta ve Shaheen, 2017).

Örgütün çalışanların işe devamını sağlamak, işten ayrılmayı azaltmak ve üretkenliği artırmak için işine adanmış çalışanlara ihtiyacı vardır. İşlerini bırakmaya karar veren deneyimli personelin işten ayrılışı, örgütler için doğrudan ve dolaylı maliyetlere yol açacaktır. Bu nedenle, çalışanların yeterli derecede adanmış olmamaları, çalışanın örgütten ayrılma niyetine yol açacaktır. İşten ayrılma niyeti maliyetlidir ve örgütü olumsuz yönde etkiler. Ayrıca işten ayrılma niyeti çalışanların yeterli hizmet sunmamasına neden olur. Bu durum örgütün verimliliğini düşürür, örgüt kültürünü ve çalışanların moralini olumsuz yönde etkiler (Salahudin, 2019:644). Robyn ve Du Preez'e göre (2013), adanmış çalışanlar örgütlerine daha fazla bağlıdırlar ve daha düşük bir terketme eğilimi gösterirler. Aynı zamanda örgütler, kalifiye çalışanlarını elde tutacak bir kültürü teşvik eden stratejiler geliştirmeye çalışmaktadır (Mxenge vd., 2014). Adanmış çalışanlar pozitif enerjiyle dolu olduklarından ve kendilerini işlerine kaptırdıklarından, örgütten ayrılmak gibi olumsuz düşünce içinde olmazlar. Yüksek düzeyde adanmışlığı olan bireylerin örgütten ayrılma olasılığı daha düşük olacaktır. Çok sayıda çalışmada, işe adanmışlık ile işten ayrılma niyeti arasında bir ilişki bulunmuştur (Salahudin, 2019: 643). Bu nedenle, işe adanmışlık ve işten ayrılma niyeti arasındaki ilişkiye yönelik aşağıdaki hipotezler sinanacaktır.

H4: Dinçlik boyutu ile işten ayrılma niyeti arasında negatif bir ilişki vardır.

H5: Adanma boyutu ile işten ayrılma niyeti arasında negatif bir ilişki vardır.

H6: Yoğunlaşma boyutu ile işten ayrılma niyeti arasında negatif bir ilişki vardır.

\subsection{Kariyer Tatmini, İşe Adanmışlık ve İşten Ayrılma Niyeti İlişkisi}

Alanyazında işe adanmışlık düzeyinin öncülleri ve sonuçlarının bulunduğu konusunda kuramsal ve görgül kanıtlar mevcuttur. Bununla birlikte örgütsel psikoloji alanyazını işe adanmışlık ve işten ayrılma niyeti arasındaki bağlantıda önemli dayanaklar sağlayamamaktadır (Plooy ve Roodt, 2010: 2). Diğer yandan, işten ayrılma niyetinin çok daha iyi anlaşılabilmesi ve işgücü devri oranının daha etkili bir şekilde yönetilebilmesi için işten ayrılma niyetinin öncüllerinin belirlenmesine de gereksinim vardır. Mevcut çalışmada işe adanmışlı̆̆ın işten ayrılma niyetinin bir öncülü olup olmadığı da araştırılmıştır. Bu ilişkinin araştırılması, çalışanların niçin daha enerjik ve sadık çalıştığı ve niçin işlerinde kaldığını açıklayan pozitif durumu ortaya koymaya yardımcı olacaktır.

İşe adanmışlık konusundaki çalışmalar, işe adanmışlığın örgütsel performans sonuçlarıyla yakından ilişkili olduğunu göstermektedir. Adanmış çalışanların oranı daha yüksek olan şirketler, işgücü devrinin ve şirketten ayrılma niyetinin azalması, üretkenlik, kârlılık, büyüme ve müşteri memnuniyetinin artması gibi sonuçlara sahiptir (Markos ve Sridevi, 2010:94). Adanmış çalışanlar, markayı güvenilir kılan müşteri hikayeleri yaratır. Aynı zamanda adanmış çalışanlar, doğrudan veya dolaylı olarak örgütlerine olumlu bir imaj yarattıklarından örgütler her zaman işe gelmeye hevesli olan ve çalışmaları konusunda çok tutkulu olan insanları ararlar. Burke 


\section{A. Anafarta - Ö. Y1lmaz 11/4 (2019) 2944-2959}

vd. (2013), çalışanların işe adanmışlı̆̆ının iş tatmini, iş performansı, işe bağlılık ve düşük düzeyde işten ayrılma gibi birçok olumlu sonuç yarattığını ifade edilmektedir. Gerçek anlamda adanmış çalışanlara sahip kuruluşlar, daha yüksek bir işte kalma, üretkenlik, müşteri memnuniyeti, yenilikçilik ve kaliteye sahiptir. Ayrıca, daha az eğitim süresi gerektirir, ekip çalışmasına inanır, işlerini üstlenir ve müşteri memnuniyeti ile uzun vadeli ilişki yönetimi sağlar (Dutta ve Sharma, 2016:184). Koyuncu vd. (2006:300), kendini işine adamış çalışanların örgütlerine yapıcı katkıda bulunmasının mümkün olduğunu belirtmişlerdir. Eğer çalışanlar işlerine ve örgütlerine kendilerini adarlarsa bu kişiler iş rollerini daha iyi gerçekleştirebilecekler, örgütlerine daha fazla bağlılık hissedebilecekler ve işlerinden ayrılmaya daha az eğilimli olacaklardır. İşine adanma düzeyi yüksek olan bir çalışan, işinden kopmakta çok zorlanacaktır. Çünkü adanmış çalışan, işi için çok fazla enerji harcamış ve yaptığı işle de kendini özdeşleştirmiştir.

Alanyazında kariyer tatmininin işten ayrılma niyetinin bir öncülü olduğu ve işten ayrılma niyetini azalttığ1 yönünde görgül kanıtlar sunan çalışmalar bulunmaktadır (Gerçek vd., 2015; Lee vd., 2016). Singh (2018), örgütsel kariyer yönetimi uygulamalarının çalışanların kariyer tatmini arttırdığını ve örgütten ayrılma niyetlerini azalttığını göstermiştir. Örgütlerde bireylerin işe adanmışlık gibi iş tutumlarının olumlu yönde ortaya çıkabilmesinde çalışanların kariyer tatmin düzeylerinin yükseltilmesi önemli ve belirleyici bir role sahip olabilir. Kariyer tatmini, işe adanmışlık ve işten ayrılma niyeti bir arada değerlendirildiğinde, çalışanların kariyer tatmin düzeylerindeki artışın her iki değişken üzerinde etkisi olacağı beklenmektedir. Bu bilgilere dayanılarak çalışmada, işe adanmışlı̆̆ın kariyer tatmini ve işten ayrılma niyeti arasındaki ilişkide aracı değişken rolü araştırılacaktır. Bu kuramsal gerekçeler ile aşağıdaki hipotezler oluşturulmuştur.

H7. Kariyer tatmini ve işten ayrılma niyeti arasında dinçlik boyutunun aracıllk etkisi vardır.

H8. Kariyer tatmini ve işten ayrllma niyeti arasında adanma boyutunun aracıllk etkisi vardır.

H9. Kariyer tatmini ve işten ayrilma niyeti arasında yoğunlaşma boyutunun aracllk etkisi vardır.

Şekil 1'de çalışmada temel alınan araştırma modeli görülmektedir. Bu modelde işe adanmışlık, alanyazına uygun olarak, dinçlik, adanma ve yoğunlaşma olmak üzere üç boyut olarak alınmıştır. Aynı zamanda yazına paralel şekilde oluşturulan hipotezler de modelde görülmektedir.

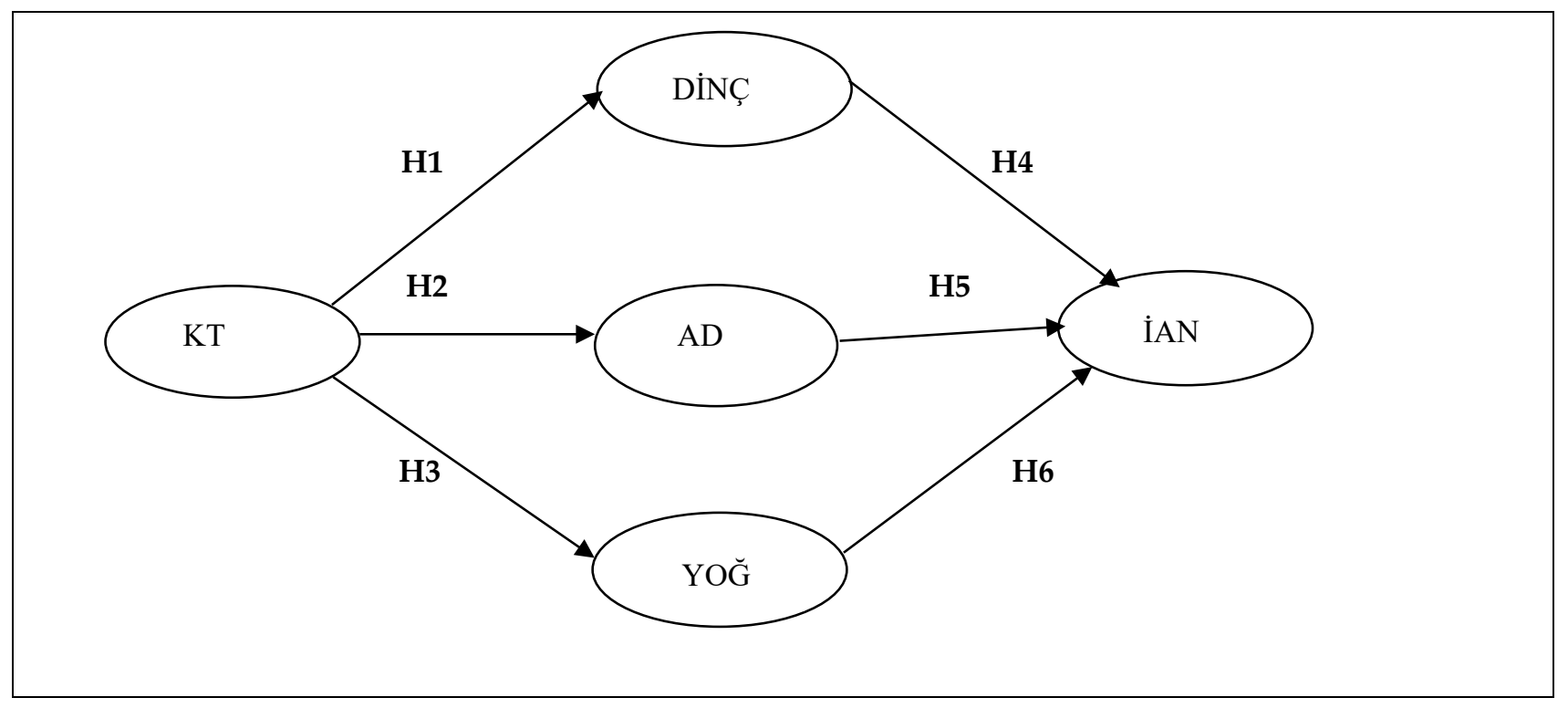

Şekil 1. Araştırma Modeli

(KT: Kariyer Tatmini, DiNÇ: Dinçlik, AD: Adanma, YOĞ: Yoğunlaşma, İAN: İşten Ayrılma Niyeti) 


\section{Yöntem}

\subsection{Veri Toplama Süreci ve Örneklem}

Veriler Antalya'da faaliyet gösteren özel bankalarda görev yapan ve araştırmaya katılmayı kabul eden çalışanlardan toplanmıştır. İşe adanmışlıkla ilgili birçok araştırmada veri genellikle tek bir firmanın çalışanlarından toplanmıştır (Mxenge vd., 2014; Gupta ve Shaheen, 2017; Dubbelt vd., 2019). Bu çalışmada verinin aynı sektördeki farklı bankalardan toplanması daha iyi bir dış geçerlilik elde etmek ve sonuçların genelliğini arttırmak amacını gütmektedir (Cook ve Campbell, 1979). Antalya merkez ilçelerde bulunan bankalara dağıtılan 500 anketten kullanılabilir 285'i geri dönmüştür. Araştırmaya katılan bankacıların \%47,4'ü kadın geri kalanı erkektir. Katılımcıların yarısı $(\% 50,9)$ evli, $\% 8,8^{\prime} \mathrm{i}$ lise, $\% 91,2^{\prime}$ si ise üniversite mezunudur. Bankacıların \%17,7'si yönetici, \%82,3'ü de memurdur.

\subsection{Veri Toplama Aracı}

Veri toplama aracı olarak anket kullanılmıştır. Anket iki bölümden oluşmaktadır. Birinci bölümde işe adanmışlık, kariyer tatmini ve işten ayrılma niyeti ölçekleri yer alırken, ikinci bölümde demografik sorulara yer verilmiştir. $\mathrm{Bu}$ araştırmada, diğer benzer alan araştırmalarında etkin olarak kullanılmış, geçerlik ve güvenirliği test edilmiş ölçeklerden faydalanılmıştır.

İşe Adanmışlık Ölçeği. Çalışanların işe adanmışlık düzeylerini ölçmek için Utrecht Work Engagement Scale (UWES) kullanılmıştır. Bu ölçek, Schaufeli vd. (2006) tarafından geliştirilmiş 7 noktalı, 17 maddeden oluşan bir ölçektir (0=Hiç, 6= Daima). Ölçek, dinçlik, adanma ve yoğunlaşma olmak üzere üç boyuttan oluşmaktadır.

Kariyer Tatmini Ölçeği. Kariyer tatmini Greenhaus vd. (1990) tarafından geliştirilen 5 maddeli ve 5’li Likert ölçeği ile ölçülmüştür (1= Hiç katılmıyorum, 5= Tamamen katılıyorum).

İşi Terketme Niyeti Ölçeği. Çalışanların işten ayrılma niyetlerini ölçmek için Cammann vd. (1983) tarafından geliştirilen ve Mimaroğlu (2008) tarafından Türkçeye çevrilen 3 maddelik işten ayrılma niyeti ölçeği kullanılmıştır. Ölçek, 5'li Likert ölçeği (1=Hiç katılmıyorum, 5=Tamamen katılıyorum) olarak yapılandırılmıştır.

Araştırmada kullanılan ölçeklerin güvenirliği Cronbach Alfa katsayısı kullanılarak değerlendirilmiş ve elde edilen sonuçlar Tablo 1'de verilmiştir. Dinçlik boyutuna ilişkin alfa değeri 0.87 'dir. Adanma boyutunu oluşturan 5 madde için alfa katsayısı 0.92 iken yoğunlaşma boyutunu oluşturan 6 madde için elde edilen alfa katsayısı 0.84 olarak bulunmuştur. İşe adanmışlık ölçeğinin genel güvenirliği ise 0.93 olarak tespit edilmiştir. Tablo 1'den kariyer tatmini ve işten ayrılma niyeti ölçeklerinin güvenirliklerinin 0.80 'in üzerinde olduğu, görülmektedir. Bu değerlere bakıldığında ölçeklerin iç tutarlılığının yeterli düzeyde olduğu söylenebilir (Hair vd., 2009).

Tablo 1. Değişkenlerin Güvenirlik Katsayısı (Cronbach Alfa)

\begin{tabular}{|l|c|c|}
\hline \multicolumn{1}{|c|}{ Ölçek } & Cronbach Alfa Değeri & Madde Sayısı \\
\hline Dinçlik & 0.87 & 6 \\
\hline Adanma & 0.92 & 6 \\
\hline Yoğunlaşma & 0.84 & 5 \\
\hline Kariyer Tatmini & 0.87 & 3 \\
\hline İşten Ayrılma Niyeti & 0.83 & 6 \\
\hline
\end{tabular}

İşe adanmışlık ölçeğinin yapı geçerliliğini test etmek için doğrulayıcı faktör analizi kullanılmıştır. Doğrulayıcı faktör analizi LISREL VIII (Jöreskog ve Sörbom, 2001) ile gerçekleştirilmiş ve üç boyutlu yapının veriye iyi 


\section{A. Anafarta - Ö. Y1lmaz 11/4 (2019) 2944-2959}

uyum sağladığ bulunmuştur (Hair vd., 2009). Uyum iyiliği kriterlerinin değerleri, $\chi 2=306.90$ (sd= 113, $\mathrm{p}=0.000$ ), $\mathrm{RMSEA}=0.078$, GFI $=0.92$ ve AGFI $=0.89$ olarak bulunmuştur.

\section{Bulgular}

\subsection{Ortalamalar ve Değişkenler Arasındaki Korelasyonlar}

Banka çalışanlarının işe adanmışlık düzeyleri dinçlik, adanma ve yoğunlaşma boyutları için sırasıyla, $3.43 \pm 0.76,3.71 \pm 0.92$ ve $3.54 \pm 0.71$ olarak bulunmuştur. İşe adanmışlık boyutları arasında işe adanma boyutunun ortalaması, diğer boyutların ortalamalarına göre daha yüksektir. Ancak banka çalışanlarının ortalama işe adanmışlık düzeylerinin çok yüksek olduğunu söylemek mümkün değildir. Banka çalışanlarının kariyer tatmin düzeylerinin de çok yüksek olmadığı söylenebilir (3.12 \pm 0.56$)$. Katılımcıların işten ayrılma niyeti ortalaması ise düşüktür $(2.50 \pm 0.75)$.

İşe adanmışlığın üç boyutu ile kariyer tatmini ve işten ayrılma niyeti arasındaki Pearson korelasyon katsayıları Tablo 2' de verilmiştir. Tablo 2 incelendiğinde, işe adanmışlık boyutları arasında anlamlı ve yüksek bir ilişki olduğu görülmektedir. İşe adanmışlığın üç boyutu ile kariyer tatmini arasında ise orta düzeyde (yaklaşık $\mathrm{r}=0.40^{\prime} l 1 \mathrm{k}, \mathrm{p}<0.01$ ) pozitif bir ilişki söz konusudur. Yani çalışanların kariyer tatminleri arttıkça dinçlik, işe adanma ve işe yoğunlaşma seviyeleri de artmaktadır. En büyük korelasyon, adanma ile kariyer tatmini arasındadır $(\mathrm{r}=0.42, \mathrm{p}<0.01)$. İşten ayrılma niyeti ile işe adanmışlık boyutları arasındaki ilişki incelendiğinde, üç boyut ile işten ayrılma niyeti arasında 0.01 seviyesinde anlamlı ve negatif bir ilişkinin olduğu görülmektedir. Kariyer tatmini ile işten ayrılma niyeti arasında negatif, zayıf bir ilişki vardır $(r=-.22, p<0.01)$.

Tablo 2. Değişkenlerin Ortalama, Standart Sapma Değerleri ve Korelasyonlar

\begin{tabular}{lccccccc}
\hline & & SS & 1 & 2 & 3 & 4 & 5 \\
& Ortalama & & & & & & \\
1. Dinçlik & 3.43 & 0.76 & - & $0.79^{* *}$ & $0.81^{* *}$ & $0.41^{* *}$ & $-0.38^{* *}$ \\
2. Adanma & 3.71 & 0.92 & - & $0.80^{* *}$ & $0.42^{* *}$ & $-0.36^{* *}$ \\
3. Yoğunlaşma & 3.54 & 0.71 & & - & $0.38^{* *}$ & $-0.37^{* *}$ \\
4. Kariyer tatmini & 3.12 & 0.56 & & & - & $-0.22^{* *}$ \\
5.İşten ayrılma niyeti & 2.50 & 0.75 & & & & - \\
\hline
\end{tabular}

${ }^{* *} \mathrm{p}<0.01$

\subsection{Araştırma Modelinin Test Edilmesi}

Şekil 1'deki Yapısal Eşitlik Modeli (YEM) LISREL VIII kullanılarak test edilmiş ve elde edilen parametre tahminleri Şekil 2'de verilmiştir. Şekil 2' deki modelin uyum iyiliği kriterleri $\chi 2=680.13(\mathrm{p}=0.000)$, RMSEA= 0.06 , GFI $=0.91$ ve $A G F I=0.86, C F I=0.96$ olarak bulunmuştur ve bu değerlerin kabul edilebilir sinırlar içinde olduğu söylenebilir (Schumacker ve Lomax, 1996). Şekil 2'deki modelden, işe adanmışlı̆̆ın adanma boyutundan (AD) işten ayrılma niyetine (İAN) giden yol hariç, tüm yol katsayılarının anlamlı olduğu görülmektedir. Bu durumda kariyer tatmini ile işe adanmışlığın üç boyutu (dinçlik, adanma ve yoğunlaşma) arasında pozitif yönlü bir ilişki olduğundan (parametre tahminleri sırasıyla $\beta=0.55, p<0.01 ; \beta=0.55, p<0.01$; $\beta=0.53, p<0.01^{\prime}$ dır) $\mathrm{H} 1, \mathrm{H} 2$ ve $\mathrm{H} 3$ hipotezleri kabul edilir. 


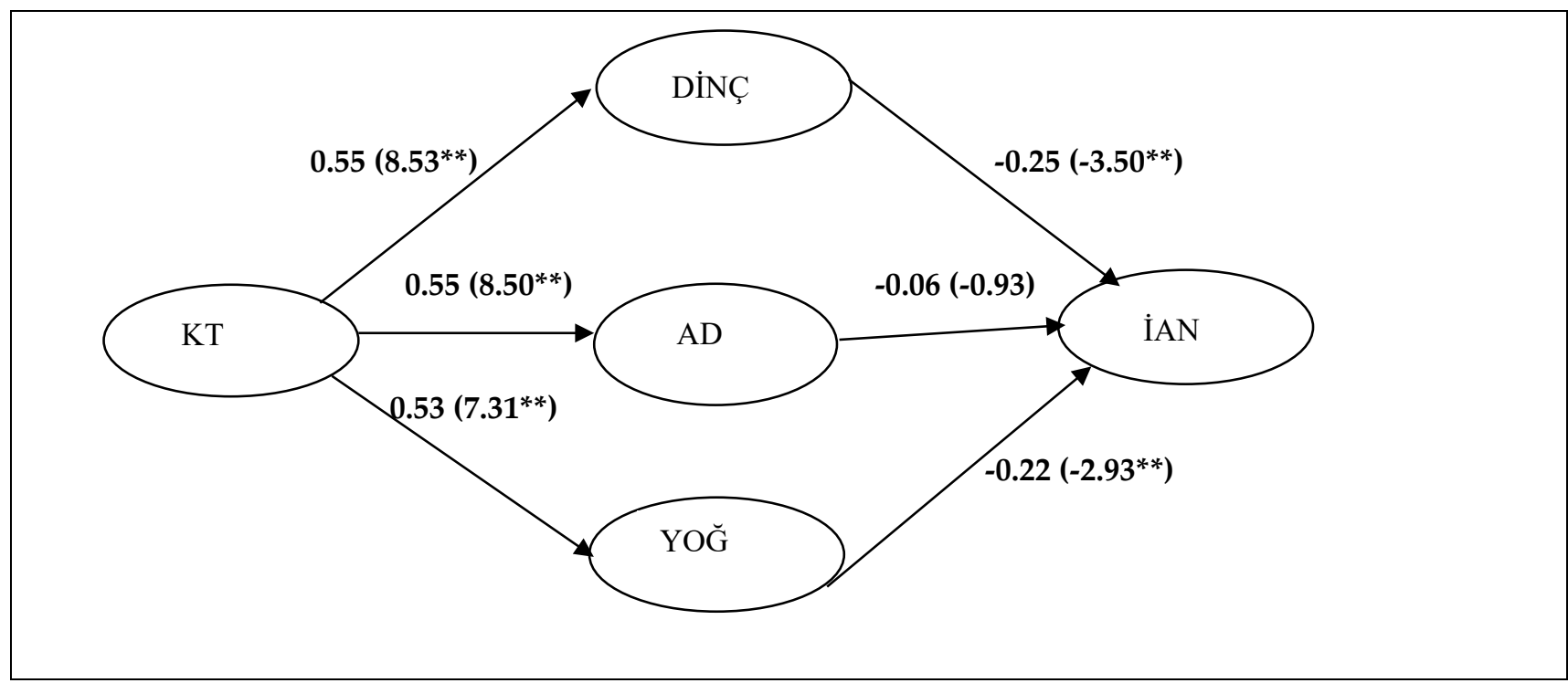

Şekil 2. Araştırma Modelinin YEM Sonuçları (**p<0.01)

İşe adanmışlık boyutlarından dinçlik ile işten ayrılma niyeti arasında negatif yönlü ve anlamlı bir ilişki olduğundan $\mathrm{H} 4$ hipotezi kabul edilir $(\beta=-0.25, \mathrm{t}=-3.50, \mathrm{p}<0.05)$. Adanma ile işten ayrılma niyeti arasında istatistiksel olarak anlamlı bir ilişki olmadığından $(\beta=-0.06, p>0.05)$ H5 hipotezi reddedilir. İşe adanmışlı̆̆ın üçüncü boyutu olan yoğunlaşma ile işten ayrılma niyeti arasında negatif yönlü ve anlamlı bir ilişkinin olması $(\beta=-0.22, t=-2.93, p<0.01)$ nedeniyle H6 hipotezi kabul edilir. Bankacıların dinçlik ve işe yoğunlaşma düzeyleri arttıkça işten ayrılma niyetlerinin azaldığı söylenebilir.

\section{3. İşe Adanmışlı̆̆ın Aracılık Rolü}

İşe adanmışlığın aracılık rolünü test etmek için iki yapısal eşitlik modeli kullanılmıştır. İlk olarak, kariyer tatmini ile işten ayrılma niyeti arasındaki doğrudan ilişkiyi test eden yapısal eşitlik modeli test edilmiş ve elde edilen sonuçlar Şekil 3'de verilmiştir. Şekil 3'deki modelin uyum iyiliği kriterleri $\chi 2=26.24$, sd= 13, p=0.015; RMSEA=0.060; GFI=0.97; AGFI=0.94 olarak bulunmuştur. Bu değerler Şekil 3'deki modelin veriye iyi uyum sağladığını göstermektedir (Hair, vd., 2009).

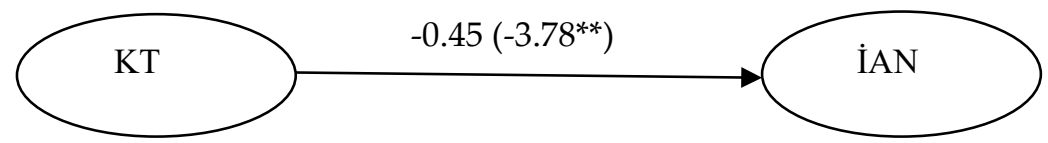

Şekil 3. Doğrudan Etki

Parametre tahmini incelendiğinde, kariyer tatmininin işten ayrılma niyeti üzerine doğrudan negatif etkisinin olduğu görülmektedir $(\beta=-0.45, \mathrm{t}=-3.78, \mathrm{p}<0.01)$.

İkinci adımda, aracılık etkisinin ikinci aşamasına geçilerek bağımlı ve bağımsız değişken arasındaki ilişki, aracı değişkenler de katılarak tekrar değerlendirilmiştir. Aracılık etkisinin varlığını gösterebilmek için bağımlı ve bağımsız değişken arasında doğrudan ilişki kurulması durumunda (Şekil 2, sınırlı model) da model uyum kriterlerinin anlamlı bir şekilde değişmemesi gerekmektedir (Zabkar, 2000). Buna göre Şekil 2' deki araştırma modeli (sınırlı model) ile Şekil 4'teki tam aracı (full mediated) modelin uyum iyiliği kriterlerinin karşılaştırılması gerekmektedir. Her iki modelin yapısal eşitlik analizi LISREL VIII ile gerçekleştirilmiş ve elde edilen uyum iyiliği kriterleri Tablo 3'de verilmiştir. Bu kriterler kabul edilebilir düzeydedir (Schumacker ve Lomax, 1996; Bollen, 1989). 
A. Anafarta - Ö. Yilmaz 11/4 (2019) 2944-2959

Tablo 3. Aracı Etkinin Fark1

\begin{tabular}{ccccccc}
\hline & Ki-kare & RMSEA & GFI & AGFI & CFI & $\begin{array}{c}\text { Ölçeklendirilmiş Ki-kare farkı } \\
\text { (Ts) }\end{array}$ \\
\hline Sinırlı Model & 680.13 & 0.06 & 0.91 & 0.86 & 0.96 & \\
Tam aracı Model & 689.44 & 0.07 & 0.94 & 0.90 & 0.97 & $1.68(\mathrm{p}=0.19)$ \\
\hline
\end{tabular}

Tablo 3' de tam aracı model ile sınırlı model'in uyum iyiliği kriterleri arasında istatistiksel olarak bir farklılığın olmadığ1 görülmektedir. Ölçeklendirilmiş Ki-kare farkının (Ts=1.68, p>0.05) istatistiksel olarak anlamlı çıkmaması, tam aracı model ile (Şekil 4) araştırma modeli (Şekil 2) arasında istatistiksel olarak bir farklılığın olmadığını göstermektedir (Önen, 2009:97). Kariyer tatmini ile işten ayrılma niyeti arasındaki ilişkide işe adanmışlı̆̆ın aracılık rolü Şekil 3 ve Şekil 4 birlikte değerlendirilerek belirlenir.

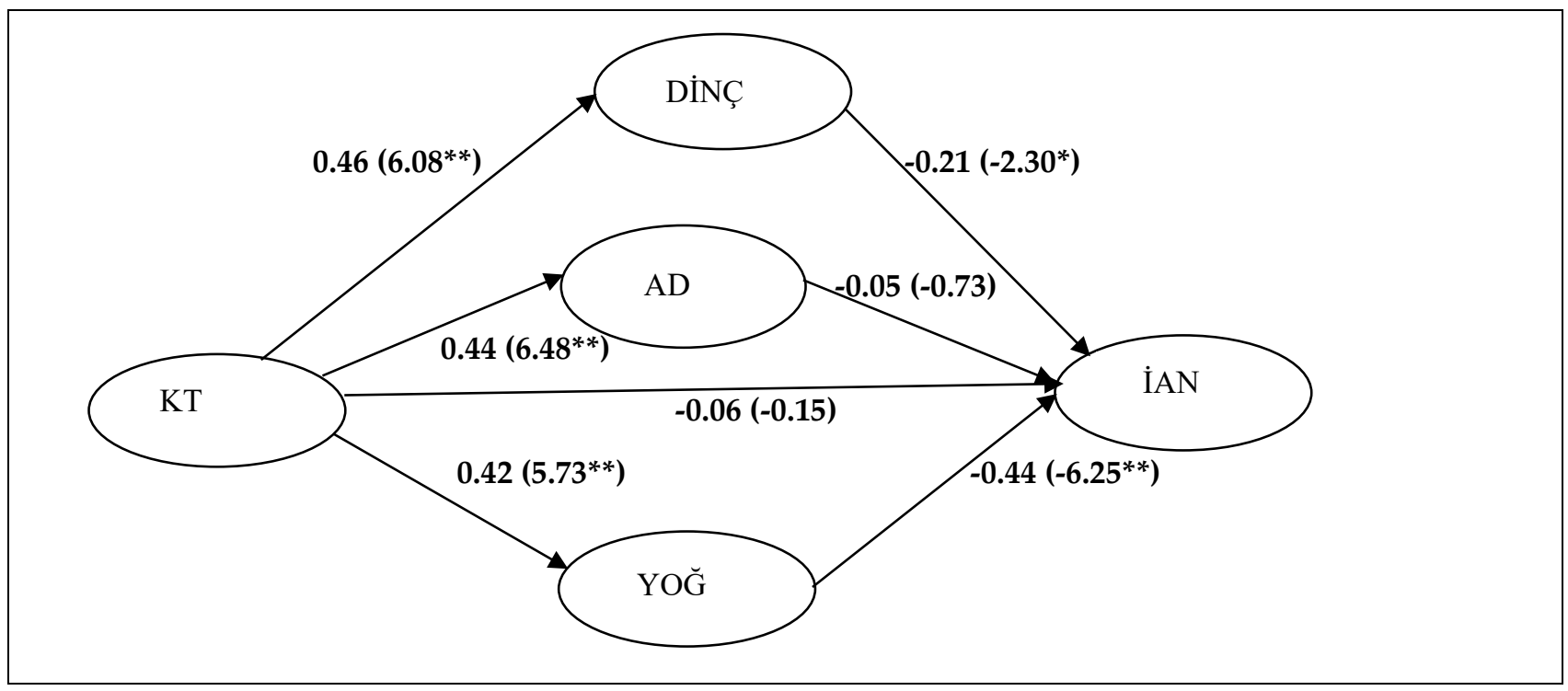

Şekil 4. Dolaylı Etkiler

Şekil 3'deki kariyer tatmini ile işten ayrılma niyeti arasındaki yol katsayısı $\beta=-0.45$ istatistiksel olarak anlamlı iken ( $\mathrm{t}=-3.78, \mathrm{p}<0.01)$, Şekil 4' deki tüm ilişkilerin birlikte ele alındığı tam aracı modelde bu katsayı istatistiksel olarak anlamsız hale gelmiştir $(\beta=-0.06, \mathrm{t}=-0.15, \mathrm{p}>0.05)$. Bu durumda $\mathrm{H} 1 \mathrm{ve} \mathrm{H} 4$ hipotezleri kabul edildiğinden ve tam modelde kariyer tatmini ile işten ayrılma niyeti arasındaki ilişki anlamsız hale geldiğinden, işe adanmışlı̆̆ın dinçlik boyutunun kariyer tatmini ile işten ayrılma niyeti arasındaki ilişkide tam aracılık etkisinin olduğu söylenir (H7 kabul). Aynı şekilde, işe adanmışlığın yoğunlaşma boyutunun kariyer tatmini ile işten ayrılma niyeti arasındaki ilişkide tam aracılık etkisinin olduğu açıtır (H9 kabul). H5 hipotezinin reddedilmesi nedeniyle adanmanın aracılık rolü yoktur ve H8 hipotezi reddedilir (Baron ve Kenny, 1986).

Bir aracllık etkisinin büyüklüğü, dolaylı etkilerle hesaplanabilir (Hair vd., 2009). Bu şekilde Tablo 4'den doğrudan ve dolaylı parametre tahminleri arasında karşılaştırma yaparak, işe adanmışlık yapısının iki boyutunun (dinçlik ve yoğunlaşma) kariyer tatmini ile işten ayrılma niyeti arasında anlamlı bir etki büyüklügüne sahip olduğu söylenebilir (Cohen, 1988). 
Tablo 4. Doğrudan, Dolaylı ve Toplam Etkiler

\begin{tabular}{rlccc}
\hline \multirow{2}{*}{ Yol } & \multicolumn{3}{c}{ Standardize edilmiş yol katsayıları } \\
& & Doğrudan etki & Dolaylı etki & Toplam etki \\
\hline I. KT $\longrightarrow$ DíNÇ & 0.46 & - & 0.46 \\
İAN & $-0.06(\mathrm{Ns})$ & -0.10 & -0.16 \\
$1 . \mathrm{KT} \longrightarrow$ AD & 0.44 & - & 0.44 \\
İAN & $-0.06(\mathrm{Ns})$ & -0.02 & $-0.08(\mathrm{Ns})$ \\
1. KT $\longrightarrow$ YOĞ & 0.42 & - & 0.42 \\
İAN & $-0.06(\mathrm{Ns})$ & -0.18 & -0.24 \\
\hline
\end{tabular}

Ns: Anlamlı değil

İşe adanmışlığın boyutlarından her birinin dolaylı etkisi incelendiğinde, dinçlik boyutunun yaklaşık -0.10

$\left(-0.21^{*} 0.46\right)$ ve yoğunlaşma boyutunun $-0.18\left(-0.44^{*} 0.42\right)$ olduğu görülmektedir. Kariyer tatminin işten ayrilma niyeti üzerindeki doğrudan etkisi -0.06 iken (Şekil 4 ve Tablo 4), dinçlik boyutu vasıtasıyla toplam etkisi 0.16 'ya, yoğunlaşma boyutunun aracıllğ 1 ile toplam etkisi de -0.24 'e yükselmiştir. Sonuç olarak kariyer tatmini ile işten ayrılma niyeti ilişkisinde öne çıkan boyutların dinçlik ve yoğunlaşma olduğu görülmektedir. Bu sonuç, kariyerlerinden tatmin olan banka çalışanlarının işte kendilerini enerjik hissettikleri ve işe konsantre oldukları ölçüde işten ayrılma niyetlerinin de azaldığını göstermektedir. Kariyerlerinden tatmin olan bankacıların işlerine yoğunlaşma düzeyleri arttıkça işten ayrılma niyetleri de azalmaktadır. Kariyer tatmini ile işten ayrılma niyeti arasında adanmanın kısmi aracılık rolünün olup olmadığı araştırıldığında adanmanın doğrudan etkisi -0.06 iken, dolaylı etkisi -0.02 olarak bulunduğundan (Tablo 4), adanma boyutunun kısmi veya tam aracilık rolü yoktur.

\section{Sonuç ve Tartışma}

Globalleşen iş dünyasında örgütler yoğun rekabetle başa çıkabilmek için yetenekli çalışanlarını elde tutmak zorundadır. Örgütün, çalışanlarını elde tutma stratejisini belirlemeye karar verdiğinde, karşılaştığı güçlüklerden birisi stratejinin oluşturulmasında etkili olan öğeleri belirlemek ve incelemektir (Mohlala vd., 2012). Bu faktörlerden ikisi çalışanların kariyer tatmini ve işe adanmışlık düzeyleridir. Mevcut çalışmada, banka çalışanlarının işe adanmışlık, kariyer tatmini ve işten ayrılma niyeti düzeyleri arasında nasıl bir ilişki olduğu, işe adanmışlı̆̆ın kariyer tatmini ve işten ayrılma niyeti arasındaki ilişkiye aracılık edip etmediği görgül olarak araştırılmıştır.

Korelasyon analizi sonuçları, kariyer tatmini ile işe adanmışlı̆̆ın üç boyutu (dinçlik, adanma ve yoğunlaşma) arasında orta düzeyde pozitif bir ilişkinin olduğunu göstermektedir. Aynı zamanda işe adanmışlık boyutları ile işten ayrılma niyeti arasında da negatif ve istatistiksel olarak anlamlı bir ilişki bulunmuştur. Halbesleben (2010)'nin yaptığı bir meta analiz çalışması, çalışanların işe adanmışlık düzeyleri ile işten ayrılma düzeyleri arasında negatif korelasyona işaret etmektedir (Caesens vd., 2014). Prouse (2010), Yeni Zelanda'da pilot ve kabin mürettebatı ile yaptığı çalışmasında işe adanmışlı̆̆ın işten ayrılma niyetini negatif etkilediğini bulmuştur. Son yıllarda yapılan bazı görgül araştırma bulguları, işe adanmışlıkla işten ayrılma niyeti arasında negatif yönlü ilişkiler olduğunu göstermiştir. Örneğin, Simons ve Buitendach (2013), işe adanmışlıkla ilgili önceki araştırmaların çoğunlukla pozitif örgütsel sonuçlardan birisi olan düşük işten ayrılma niyetiyle ilişkili olduğunun altını çizmiştir. Mokaya and Kipyegon (2014)'un Kenya'da bir bankanın 214 çalışanı ile yaptıkları araştırmada işe adanmışlığın performans yönetimi, kişisel gelişim, işyeri rekreasyonu ve ücretten büyük ölçüde etkilendiği bulunmuştur. Çalışanın işe adanmışlı̆̆ı, müşteri sadakati ve performans üzerinde etkisi 


\section{A. Anafarta - Ö. Yılmaz 11/4 (2019) 2944-2959}

olan bankacılık hizmetinin kalitesini etkilemektedir. Adanmış çalışanlara sahip olan bankalar, bu kişilerin enerjik, özverili ve işlerine karşı tutkulu olmaları nedeniyle daha yüksek bir çalışan performansına ve daha düşük bir işgücü devrine sahiptir. (Memon vd., 2018), Pakistan'daki bir bankanın farklı hiyerarşik kademelerinde görev yapan 127 çalışanlarla yaptıkları bir araştırmada çalışanların kişisel başarılarının yanısıra örgütün başarısına katkıda bulunan iş uygulamalarının yüksek adanmışlık sağlamak ve yüksek oranda çalışmaya devam etmek suretiyle çalışanlarının performansını arttırdığını bulmuşlardır.

Yapısal eşitlik modelinden elde edilen önemli bulguların birisi, çalışanların kariyer tatminlerindeki artışın işe adanmışlık düzeylerini arttırdığını ortaya koymaktadır. Çalışanlar kariyer hedefleri ve beklentilerinin karşılanması sonucunda tatmin olduklarında, işleriyle ilgili daha fazla olumlu ve tatminkar bir durum deneyimleyebilirler. Çin'de yapılan bir çalışma, kariyer tatmini ve işe adanmışlık arasında pozitif yönlü bir ilişkinin varlığını ortaya koymuştur (Guan vd., 2014). Yine Pakistan'da yapılan bir çalışmada, işe adanmışlık, kariyer tatmini ve örgütsel bağlılık arasında önemli pozitif ilişkiler elde edilmiştir (Khalid ve Khalid, 2015).

Çalışmanın diğer önemli bir bulgusu da kariyer tatmini ile işten ayrılma niyeti arasında doğrudan ilişkinin negatif, anlamlı ve orta düzeyde olmasıdır. Yani banka çalışanlarının kendi hedeflerine ulaşmada elde ettikleri çıktıları ve başarıları olumlu olarak değerlendirmeleri, işten ayrılma niyetlerini azaltmaktadır. Bu bulgu, alanyazındaki görgül bulgularla uyumludur. Ancak alanyazın incelemesi kariyer tatmini ve işten ayrıma niyeti ilişkisinin genellikle yöneticiler ve profesyoneller açısından ele alındığını göstermiştir. Mevcut çalışmada söz konusu ilişkinin faklı düzeylerden katılımcılar açısından incelenmesi alanyazının genişletilmesine katkıda bulunacaktır. Amerika'da yapılan bir çalışmada alt ve orta düzey yöneticilerin kariyer tatminleri ile işten ayrılma niyetleri arasında zayıf yönlü bir ilişki saptanmıştır (Eddletton, 2009). Singh (2018) örgütsel kariyer yönetimi uygulamalarının kariyer tatminlerini arttırdığını ve çalışanların işten ayrılma niyetlerini azalttığını göstermiştir. Kanada örgütlerinde profesyoneller ve yöneticilerle yapılan bir araştırma, kariyer tatmininin örgütsel başarı ve büyüme üzerinde etkili olan daha düşük işgücü devrine neden olduğunu ortaya koymuştur (Yap vd., 2014). Koyuncu vd. (2006)'nin banka çalışanı kadın yöneticilerle yaptığı inceleme çalışanların kariyer tatminlerinin işten ayrılma niyeti düzeyini düşürdüğünü ortaya koymuştur. Beyaz yakalılarla yapılan bir çalışma ise kariyer tatmininin işten ayrılma niyeti üzerinde negatif yönlü bir etkisinin olduğunu göstermiştir (Gerçek vd., 2015: 81).

Yapısal eşitlik modelinin bulguları, çalışanların işe adanmışlıklarının işten ayrılma niyetleri üzerindeki rolünü, arasındaki ilişkinin yapısını ve boyutunun anlaşılmasını sağlamıştır. Mevcut araştırmada, işe adanmışlık boyutlarından dinçlik ve yoğunlaşmanın işten ayrılma niyeti üzerinde etkili olduğu ancak adanma boyutunun yapısal model içerisinde işten ayrılma niyetini etkilemediği görülmektedir. Bu sonuç, banka çalışanlarının kariyer tatmin düzeyleri yükseldikçe, işe adanmışlıkları vasıtasıyla işten ayrılma niyetlerinin azaldığı anlamına gelmektedir. Diğer bir ifadeyle örgütler, çalışanlarının kariyer tatminlerinin yol açtığı işten ayrılma niyeti düzeylerini azaltmak için onların işe adanmışlıklarından yararlanabilirler. Aynı zamanda işe adanmışlık düzeyi, özellikle yoğunlaşma boyutu yüksek olan çalışanların diğer çalışanlara nazaran işlerinde daha fazla mutlu olmaları ve işlerinde zamanın hızlı geçtiğini hissetmeleri nedeniyle işlerinden ayrılmayı daha az düşünmeye eğilimli olacakları açıktır. Schaufeli ve Bakker (2004) işe adanmışlığın üç boyutunun işten ayrılma niyetinin bir öncülü olduğunu, aralarında negatif yönlü bir ilişki bulunduğunu ve iş kaynakları ile işten ayrılma niyeti arasındaki ilişkide aracılık rolü oynadığını bulmuştur. Burke vd. (2013), işe adanmışlığın temel sonuçlarının artan iş tatmini ve düşük işten ayrılma niyeti olduğunu vurgulamışlardır. Gökarslan (2018)'ın öğretmenlerle yaptığı bir araştırmada, işe adanmışlık ve işten ayrılma niyeti arasında negatif yönlü anlamlı ilişki olduğu bulunmuştur $(\mathrm{r}=-0.28, \mathrm{p}<0.01)$. Kore örgütlerinde yapılan bir çalışmada ise işgören devir hızı ile işe adanmışlık arasında $r=-0.36$ ( $<<0.01$ ) düzeyinde bir ilişki bulunmuştur (Kim vd., 2019). Salahudin vd. (2019) tarafından Brunei Sultanlığındaki 119 bankacı ile yapılan araştırmada işe adanmışlığın, katılımcıların işten ayrılma niyetlerini önemli ölçüde etkilediği görülmüştür. Bankacılık sektörünün giderek büyümesi ve gelişmesi, bankaların ileri teknoloji, hızlı iletişim sistemi gibi sinırlı olmayan hizmetler ile kitlelere ulaşmaya çalışması, çokuluslu liderlik ortamına ayak uydurabilmesi bu sektörü önemli kılmaktadır. Bankacılık sektöründe adanmış, uyumlu ve tanıdık çalışanlar, müşteri deneyimini geliştirmek için daha çok çalışacak ve daha büyük hissedar değeri üretecektir.

$\mathrm{Bu}$ araştırma, hem kariyer tatmininin hem de işe adanmışlığın banka çalışanlarının işten ayrılma niyetlerini tahmin etmede önemli olduğunu göstermiştir. Araştırma banka çalışanlarının işe adanmışlıkları, kariyer tatmin düzeyleri ile işten ayrılma niyetleri arasında aracılık eden bir ilişki olduğunu ortaya koymaktadır. Bu 


\section{A. Anafarta - Ö. Y1lmaz 11/4 (2019) 2944-2959}

nedenle, işe adanmışlık, banka çalışanlarının kariyer tatminlerinin çalışanların işten ayrılma niyetleri üzerindeki etkisine aracılık eder ve pekiştirir. Banka insan kaynakları yöneticileri, çalışanlarının kariyer tatminine odaklanmalıdır. Birçok araştırmanın sonuçları kurumsal kariyer programlarının (örneğin eğitim ve gelişim fırsatları, kariyer desteği ve danışmanlık) çalışanların kariyer tatminleri ile güçlü bir şekilde ilişkili olduğunu gösterdiğinden, bankalardaki insan kaynakları yöneticileri çalışanların kariyer tatminlerine odaklanıp çalışanların işe adanmasını ve elde tutulmasını sağlayabilir. Banka yönetiminin, çalışanın işe adanmışlığı üzerinde etkisi olan program ve politikalarını geliştirirken, çevresel faktörlerin etkisinin yanı sıra ihtiyaçlarının farkında olması ve işgücünü oluşturması önemlidir. Bankaların, çalışanlarıyla güvene dayalı bir ilişki kurmaları gerekir, çünkü mükemmel hizmet sunumu bankaların en önemli özelliklerden biridir. İş sonuçlarına ve müşteri memnuniyetine yol açtı̆̆ından, banka yöneticileri çalışanların tutum ve davranışlarını etkileyerek çalışanların adanmışlığına yatıım yapmalıdırlar. Banka yöneticileri her çalışanın işlerini ve bu işleri yapmanın en etkili yöntemini anlatan sürekli eğitimlerle çalışanların bilgi ve becerilerini geliştirmeye devam etmelidirler. Devam eden eğitim süreci, çalışan performansını sürekli olarak artırmak için en iyi yaklaşımdır.

$\mathrm{Bu}$ araştırmanın bulguları, işe adanmışlık ve kariyer tatminini geliştirici programların hazırlanmasının çalışanları elde tutma olasılığını artırabileceği gerçeğini ortaya koymaktadır. İnsan kaynakları yöneticileri kariyer tatminini iyileştiren ve işe adanmışlığı arttıran bir araç olarak çalışanlar için yardım programları düzenlemelidirler. Yöneticiler uygun eğitimler vererek çalışanların bilgi ve becerilerini arttırmalarına yardımcı olunmalıdır. İşleriyle ilgili daha fazla bilgi sahibi olduklarında, çalışanların öz-yeterlikleri ve güvenlerindeki artışa bağlı olarak kariyerlerinden tatmin düzeyleri de artacaktır. Ayrıca çalışanların işe adanmışlık düzeylerinin düzenli olarak araştırılması, çalışanların ilgisini çeken faktörlerin ortaya çıkmasına yardımcı olur. İşe adanmışlığı teşvik eden tüm faktörlerin belirlenmesi, çalışanlar için en büyük farkı yaratacak faktörler üzerine yoğunlaşılması ve bu alanların iyileştirilmesi için enerji harcaması önemlidir. Örgüt tarafından çalışanlara iş ve iş dışındaki yaşamları ve kariyerlerini planlama ile ilgili yardımcı olunması kariyerlerinden daha fazla tatmin olmalarına, işlerine daha fazla adanmalarına ve işlerinden ayrılmayı daha az düşünmelerine yol açacaktır. Örgütler çalışanlarına daha iyi kariyer yolları çizme ve planlama olanağı sağlayarak kariyer tatminlerini arttırabilirler. Örneğin, hem teknik hem de yönetsel kariyer yolu olanaklarına izin veren ikili bir kariyer merdiveni buna yardımcı olabilir. Bu konuda çalışanlara mentorluk hizmeti sunulmalıdır. Yöneticiler için de konunun önemi ve nasıl gerçekleştirilebileceği konusunda seminer ve hizmet içi eğitim programları oluşturmalıdırlar.

Örgütler çalışanlarının yaptıkları işleri önemli bularak içselleştirmelerine olanak vermelidirler. Böyle bir ortam çalışanlarda içsel motivasyon artışı sağlayabileceğinden işe adanmışlık düzeylerinde de artışlar sağlanabilir. Kariyer planlama gereksinimleri farklı kültürlerde farklı olarak yorumlanabileceğinden ve çalışanlar kariyerlerinden farklı biçimlerde ve derecelerde tatmin edilebileceğinden hareketle, insan kaynakları yöneticileri bu gereksinimlerin doyurulması için gerekli stratejiler geliştirmelidirler. Diğer yandan örgütler yetenekli çalışanlarını elde tutmak için işe adanmalarını sağlayan bir işletme kültürü oluşturmaya çalışmalı ve bu konuda stratejiler geliştirmelidirler.

Gelecekte, işe adanmışlık ile kariyer arasındaki ilişkiyi entegre bir çerçevede sentezleyen akademik alan araştırmaları ve meta-analiz çalışmalarının yapılması önerilmektedir. Mevcut çalışmaya kariyer tatmini yanısıra, kariyer başarısı, kariyer bağlılığı, örgütsel kariyer yönetimi uygulamaları gibi değişkenler de eklenebilir. Farklı sektörlerde aynı değişkenler ile araştırmayı tekrarlamak bu çalışma bulgularının genelleştirilmesine katkı sağlayacaktır. Ayrıca sonuç değişken olarak işten ayrılma niyetine tükenmişlik, performans gibi değişkenler eklenerek mevcut araştırma genişletilebilir. 


\section{KAYNAKÇA}

Al-Shbiel, S. O., Ahmad, M. A., Al-Shbail, A. M., Mawali, H. A. ve Al-Shbail, M. O. (2018). The mediating role of work engagement in the relationship between organizational justice and junior accountants turnover intentions, Accounting and Financial Studies Journal, 22(1), 1-23.

Anafarta, N. (2015). Job satisfaction as a mediator between emotional labor and the intention to quit, International Journal of Business and Social Science, 6(2), 72-81.

August, L.ve Waltman, J. (2004). Culture, climate, and contribution: Career satisfaction among female faculty, Research in Higher Education, 45(2), 177-192.

Bakker, A. B., Demerouti, E. ve Sanz-Vergel, A. I. (2014). Burnout and work engagement: The JD-R approach, Annual Review of Organizational Psychology and Organizational Behavior, 1, 389-411.

Bakker, A. B. ve Leiter, M. P. (2010). Work Engagement, a Handbook of Essential Theory and Research. New York, Psychology Press.

Bakker, A. B. ve Simon, A. (2018). Work engagement: current trends, Career Development International, 23(1), $4-11$.

Barnes, D. C. ve Collier, J. E. (2013). Investigating work engagement in the service environment, Journal of Services Marketing, 27(6), 485-499.

Barnett, B. R.ve Bradley, L. (2007). The impact of organisational support for career development on career satisfaction, Career Development International,12(7), 617-636.

Baron, R. M. ve Kenny, D. A. (1986). The moderator-mediator variable distinction in social psychological research: conceptual, strategic, and statistical considerations, Journal of Personality and Social Psychology, 51(6), 1173-1182.

Bollen, K. A. (1989). Structural Equations with Latent Variables. New York, John Wiley and Sons, Inc.

Burke, R. J., Koyuncu, M., Tekinkuş, M., Bektaş, Ç. ve Fiksenbaum, L. (2012). Work engagement among nurses in turkish hospitals: potential antecedents and consequences, Is, Guc, Industrial Relations and Human Resources Journal, 14(1), 7-24.

Burke, R. J., Koyuncu, M., Fiksenbaum, L. ve Tekin, Y. (2013). Antecedents and consequences of work engagement among frontline employees in Turkish hotels, Journal of Transnational Management, 18(3), 191-203.

Caesens, G., Stinglhamber, F. ve Marmier, V. (2014). The curvilinear effect of work engagement on employees' turnover intentions, International Journal of Psychology, 1-7.

Chughtai, A. ve Buckley, F. (2011). Work engagement: Antecedents, the mediating role of learning goal o rientation and job performance, Career Development International, 16(7), 684-705.

CIPD, (2017). Resourcing and Talent Planning survey access Rertived from: https://www.cipd.co.uk/Images/resourcing-talent-planning_2017_tcm18-23747.pdf

Cohen, J. (1988). Statistical Power Analysis for the Behavioral Sciences (2nd ed.). Hillsdale, NJ, Lawrence Erlbaum Associates, Publishers.

Cook, T. D. ve Campbell, D. T. (1979). Quasi- Experimentation: Design and Analysis Issues for Field Settings, Chicago, Rand-Mcnally.

Dubbelt, L., Demerouti, E, ve Rispens, S. (2019). The value of job crafting for work engagement, task performance, and career satisfaction: longitudinal and quasi-experimental evidence, European Journal of Work and Organizational Psychology, 28(2), 1-16.

Dutta, H. ve Sharma S. (2016). Employee engagement in Indian banking sector: A Review of the literature, International Conference on Management and Information Systems September 23-24, 2016. ISBN 978-1943295-04-3. https://www.researchgate.net/publication/307937391.

Eddleston, K. A. (2009). The effects of social comparisons on managerial career satisfaction and turnover intentions, Career Development International, 14(1), 87-110. 


\section{A. Anafarta - Ö. Y1lmaz 11/4 (2019) 2944-2959}

Gerçek, M., Atay, S. E. ve Dündar, G. (2015). Çalışanların iş-yaşam dengesi ile kariyer tatmininin, işten ayrılma niyetine etkisi, KAÜ İ̈BF Dergisi, 6(11), 67-86.

Gökaslan, M. O. (2018). Öğretmenlerde örgütsel bağlllık, işe gömülmüşlük, işe adanmışlık ve işten ayrılma niyeti ilişkisi: Bir alan çalışması, Türk Sosyal Bilimler Araştırmaları Dergisi /Journal Of Turkish Social Sciences Research, 3(2), 25-46.

Greenhaus, J. H., Parasuraman, S. ve Wormley, W. M. (1990). Effects of race on organizational experiences, job performance evaluations, and career outcomes, Academy of Management Journal, 33(1), 64-86.

Guan, Y., Wen Y., Chen, X. S., Liu, H., Si, W., Liu, Y., Wang, Y., Fu, R., Zhang, Y. ve Dong, Z., (2014). When do salary and job level predict career satisfaction and turnover intention among Chinese managers? The role of perceived organizational career management and career anchor, European Journal of Work and Organizational Psychology, 23(4), 596-607.

Gupta, M. ve Shaheen, M. (2017). Impact of work engagement on turnover intention: moderation by psychological capital in India, Theory and Practice,18, 136-143.

Hair, J. F., Black, W. C., Babin, B. J. ve Anderson, R. E. (2009). Multivariate Data Anaysis, Seventh Edition, New Jersey, Prentice Hall.

İnce, A. R. (2016). Algılanan örgütsel desteğin işe adanmışlık üzerindeki etkisinde yönetici desteğinin aracılık rolü, Elektronik Sosyal Bilimler Dergisi, 15(57), 649-660.

Jiang, J. J., Klein, G. ve Balloun, J. (2001). The joint impact of internal and external career anchors on entry-level is career satisfaction, Information and Management, 39(1), 31-39.

Joo, B. K. ve Lee, I. (2017). Workplace Happiness: Work Engagement, Career Satisfaction, and Subjective WellBeing, Evidence-based HRM: A Global Forum for Empirical Scholarship, 5(2), 206-221.

Jöreskog, K. G., ve Sörbom, D. (2001). Lisrel 8: User's Reference Guide, Chicago: Scientific Software International.

Kane-Frieder, R. E., Hochwarter, W. A. ve Ferris, G. R. (2014). Terms of engagement: Political boundaries of work engagement-work outcomes relationships, Human Relations, 67(3), 357-382.

Kartal, H., İşler L. ve Bilişli, Y. (2015). Örgütsel bağlılık ve işle bütünleşmenin işten ayrılma niyetine etkisi: Çağrı merkezi örneği, Electronic Journal of Vocational Colleges, 325-338.

Khalid, A. ve Khalid, S. (2015). Relationship between organizational commitments, employee engagement and career satisfaction: A case of University of Gujrat, Pakistan, Journal of South Asian Studies, 3(3), 323330.

Kim, W., Han, S. J. ve Park, J. (2019). Is the role of work engagement essential to employee performance or nice to have'? Sustainability, 11 (4), 1050.

Koyuncu, M., Burke, R. J. ve Fiksenbaum, L. (2006). Work engagement among women managers and professionals in a Turkish bank, Equal Opportunities International, 25(4), 299-310.

Langelaan, S., Bakker, A. B., Doornen, L. J. P. ve Schaufeli, W. B. (2006). Burnout and work engagement: do individual differences make a difference? Personality and Individual Differences, 40, 521-532.

Lee, Y., Kwon, K. Kim, W. ve Cho, D. (2016). Work engagement and career: proposing research agendas through a review of literature, Human Resource Development Review, 15 (1), 29-54.

Lounsbury, J. W., Steel, R. P., Gibson, L. W. ve Drost, A. W. (2008). Personality traits and career satisfaction of human resource professionals, Journal Human Resource Development International, 11(4), 351-366.

Markos, S. ve Sridevi, S. M. (2010). Employee engagement: The key to improving performance, InternationalJournal of Business and Management, 5 (12), 89-96.

Martins, L. L., Eddleston, K. A. ve Veiga, J. F. (2002). Moderators of the relationship between work-family conflict and career satisfaction, Academy of Management Journal, 45(2), 399-409.

May, D. R., Gilson R. L. ve Harter, L. M. (2004). The psychological conditions of meaningfulness, safety and availability and the engagement of the human spirit at work, Journal of Occupational and Organizational Psychology, 77, 11-37.

Memon, S. B., Soomro B. S., Kumar S. (2018). Assessing the work engagement, work practices and work performance in banks, Journal of Administrative and Business Studies (JABS), 4(3), 165-184. 


\section{A. Anafarta - Ö. Y1lmaz 11/4 (2019) 2944-2959}

Mohlala, J., Goldman, G. A. ve Goosen, X. (2012). Employee retention within the information technology division of a South African Bank, SA Journal of Human Resource Management, 10(2), 1-11.

Mokaya, S. O. ve Kipyegon, M. J. (2014). Determinants of employee engagement in the banking industry in Kenya; Case of Cooperative Bank, Journal of Human Resources Management and Labor Studies, 2 (2), 187200.

Mxenge, S. V., Dywili, M. ve Bazana, S. (2014). Job engagement and employees' intention to quit among administrative personnel at the University of Fort Hare in South Africa, International Journal of Research In Social Sciences, 4(5), 129-144.

Mimaroğlu, H. (2008). Psikolojik Sözleşmenin Personelin Tutum ve Davranışlarına Etkileri: Tıbbi Satış Temsilcileri Üzerinde Bir Araştırma, Doktora Tezi, Çukurova Üniversitesi, Sosyal Bilimler Enstitüsü, Adana.

Önen, E. (2009). Ölçme Değişmezliğinin Yapısal Eşitlik Modelleme Teknikleri ile İncelenmesi, Doktora Tezi Ankara Üniversitesi Eğitim Bilimleri Enstitüsü.

Özgen, H. ve Yalçın, A. (2010). İnsan Kaynakları Yönetimi Staratejik Bir Yaklaşım, Adana, Nobel Kitapevi.

Pienaar, J. ve Willemse, S. A. (2008). Burnout, engagement, coping and general health of service employees in the hospitality industry, Tourism Management,29 (6), 1053-1063.

Plooy, D. J. ve Roodt, G. (2010). Work engagement, burnout and related constructs as predictors of turnover intentions: original research, Home / SA Journal of Industrial Psychology, 36(1), 1-13.

Pollak, A, Pniak, M.C., Rudnicka, P. ve Paliga, M. (2017). Work engagement - a systematic review of polish research, Polish Psychological Bulletin, 48 (2), 175-187.

Prouse, E. (2010). The influences of work engagement and intention to turnover in pilots and cabin crew in a New Zealand based Airline organisation, A thesis presented in partial fulfillment of the requirements for a degree of Master of Science in Psychology, Massey University, Palmerston North New Zealand.

Robert, D. R. ve Davenport, T. A. (2002). Job engagement: why it's important and how to improve it, Employment Relation, 29(3), 21-29.

Robyn, A. ve Du Preez, R. (2013). Intention to quit amongst generation Y academics in higher education, $S A$ Journal of industrial Psychology, 39 (1), 1-14.

Ryan, R. M. ve Deci, E. L. (2000). Self-determination theory and the facilitation of intrinsic motivation, social development and well-being, American Psychologist, 55(1), 68-78.

Saks, A. M. (2006). Antecedents and consequences of employee engagement, Journal of Managerial Psychology, 21(7), 600-619.

Salahudin, S. N., Ramli, H. S., Alwi, M. N. R., Abdullah, M. S. ve Rani, N. A. (2019). Employee engagement and turnover intention among Islamic bankers in Brunei Darussalam, International Journal of Recent Technology and Engineering (IJRTE), 8 (2S).

Schumacker, E. R. ve Lomax, G. R. (1996). A beginner's guide to structural equation modeling. Mahwah, NJ, Erlbaum.

Schaufeli, W. B., Salanova, M., Gonzalez-Rom, V. ve Bakker, A. B. (2002). The measurement of engagement and burnout: a two sample confirmatory factor analytic approach, Journal of Happiness Studies, 3, 71- 92.

Schaufeli, W. B. ve Bakker, A.B. (2004). Job demands, job resources, and their relationship with burnout and engagement: a multi-sample study, Journal of Organizational Behavior, 25, 293-315.

Schaufeli, W. B., Bakker, A. B., Salanova, M. (2006). The measurement of work engagement with a short questionnaire a cross-national study, Educational and Psychological Measurement, 66(4), 701-716.

Shaver, K. H. ve Lacey, L. M. (2003). Job and career satisfaction among staff nurses: Effects of job setting and environment, The Journal of Nursing Administration, 33(3), 166-172.

Shimazu, A, Schaufeli, W. B., Kamiyama, K. ve Kawakami, N. (2015). Workaholism vs. work engagement: The two different predictors of future well-being and performance, International Journal of Behavioral Medicine, 22(1), 18-23. 


\section{A. Anafarta - Ö. Yilmaz 11/4 (2019) 2944-2959}

Simons, J. C. ve Buitendach, J. H. (2013). Psychological capital, work engagement and organisational commitment amongst call center employees in South Africa, SA Journal of Industrial Psychology, 39(2), 112.

Singh, S. (2018). Organizational career management practices, career satisfaction, and intention to quit among

Indian employee: Examining the moderating effect of 'four types of work experience, Australian Journal of Career Development, 27(3) 150-159.

Takawira, N., Coetzee, M. ve Schreuder, D. (2014). Job embeddedness, work engagement and turnover intention of staff in a higher education institution: an exploratory study, SA Journal of Human Resource Management, 12(1).

Timms, C. ve Brough, P. (2013). "I like being a teacher": Career satisfaction, the work environment and work engagement, Journal Of Educational Administration, 51(6), 768-789.

Venkatesh, J. ve Lissy, T. A . (2014). A Study on relationship between employee engagement factors and organizational commitment in private banking sector. Intl. J. Bus. Administration Res. Rev., 2, 209- 217.

Wright, T. A. ve Bonett, D. G. (2007). Job satisfaction and psychological well-being as nonadditive predictors of workplace turnover, Journal of Management, 33(2), 141-160.

Yang, J. T., Wan, C. S., ve Fu, Y. J. (2012). Qualitative examination of employee turnover and retention strategies in international tourist hotels in Taiwan, International Journal of Hospitality Management, 31(3), 837-848.

Yap, M., Cukier, W., Holmes, M. R. ve Hannan, C. A. (2010). Career satisfaction: A look behind the races, Relations Industrielles/Industrial Relations, 65 (4), 584-608.

Yap, M., Holmes, M., Hannan, C. ve Cukier, W. (2014). Correlates of career satisfaction in Canada- the immigrants' experience, Int. Migration \& Integration, 15, 49-71.

Zabkar, V. (2000). Some methodological issues with structural equation model application in relationship quality context. New Approaches in Applied Statistics. Metodološki zvezki, Ljubljana. 